\title{
Ernst Mach and Wolfgang Pauli's Ancestors in Prague
}

By František Smutný

\section{SUMMARY}

The Swiss physicist Wolfgang Pauli (1900-1958) descends from a notable Jewish family of publishers and booksellers at Prague. This essay presents biographical data and Prague fortunes of his father, grandfather and greatgrandfather. The roots of friendship between Wolfgang Pauli's father and the family of Ernst Mach, then professor at the university of Prague, are documented and a hypothesis is suggested concerning motives that induced Wolf Pascheles, Wolfgang Pauli's father, to choose just "Pauli" as his new surname.

"The past is head-turning" Karel Čapek

\section{Preamble}

In view of a biography of the most famous Swiss physicist after Einstein, Wolfgang Pauli (1900-1958), the undersigned planned to do some research on Pauli's grandfather in Prague while visiting in spring 1986 for a physics meeting to be held in Liblice. To this end I had asked the organizer of this meeting, Dr. V. Dvořák from the Czechoslovak Academy of Sciences, in late 1985 whether he could propose somebody to help me in the mentioned task. Dr. Dvořák's proposition of a colleague of his was a very lucky one, and I am most grateful to him.

Indeed, the very first letter that Dr. František Smutný wrote me on 28 January 1986, in which he expressed his surprise at learning that Pauli's family had lived in Prague, already contained everything I had wished to find out. The following essay, however, contains much more. It is the fruit of Dr. Smutný's passionate and truly professional research but also of his imaginative speculations about some of the unresolved problems.

I find Dr. Smutnýs essay so well done that any addition on my part would have perturbed the exciting narrative of facts and fancies. I 
therefore decided to refrain from being a co-author of a joint paper in order not to create any ambiguity as to whose merit this work is. I must add, however, that the initial information on grandfather Pascheles and his wife, as well as the information contained in references 1, 14 and 15 below were supplied to me by my colleague Professor Hans Warhanek from the University of Vienna and his wife. I wish to thank both of them for having given me very precious documents and information, contained in a letter dated 19 June 1986, concerning Wolfgang Pauli's roots in Vienna. But this is a different chapter of Pauli's biography.

A first version of Dr. Smutný's manuscript was published in Czech in Československý časopis pro fyziku A 38, 632-638 (1988). The present manuscript is his English translation edited by me.

Charles P. Enz

\section{1 - Introduction}

At the beginning of the academic year 1899/1900, Pauli's father, "M. univ. Dr.", as it used to be abbreviated in Austria in those days, became a private docent of internal medicine at the University of Vienna ${ }^{1}$. The following year, on 25 April, Wolfgang Pauli was born and Ernst Mach, then "Professor of Philosophy, particularly for the History and Theory of Inductive Sciences" at the same university stood godfather to him. Mach's marked intellectual influence on both, father and son Pauli and the deep friendship between father Pauli and the Machs has been stressed by Wolfgang Pauli himself ${ }^{2}$. Since Ernst Mach retired on 1 May 1900, the coinciding careers of father Pauli and godfather Mach at the University of Vienna are patently too short to make adequate room for the development of close connections between a young newcomer and a famous scientist. Even the godfathership alone was an honour, hardly deserved within the space of contacts at the university during less than one academic year.

This puzzle was the strongest motive for the investigations underlying this essay which, I admit, though based on new facts, reads like a fable of sorts. Although the main purpose is to present unknown biographical data on Wolfgang Pauli's ancestors and their connections with Ernst Mach and his family, I wish to include the following query: On two unrelated occasions, having discussed the godfathership of Prof. Mach with physicist colleagues interested in history, I encountered their curiosity as to the compatibility of Mach's high-principled (sometimes fighting) atheism with his active partici- 
pation in a religious ceremony. I believe, the material presented in this article will enable us to suggest a satisfactory explanation.

\section{2 - Wolfgang Pauli's descent}

The Pascheles Publishing House originated by sheer chance: When cholera appeared in Prague for the first time in 1831, the Rabbinate ordered as a proper prayer the selichot (liturgical poems recited as prayers of repentance and/or forgiveness) of rabbi Eliezer Ashkenazi, the text of which was not commonly known and was circulated mostly in transcripts.

A certain Wolf Pascheles (11 May 1814, Prague-22 November 1857, Prague), then 17, who at the age of fourteen had compiled a German prayerbooklet for women and earned his living as a tutor in wealthy families in Prague and its surroundings, promptly published his prayer-booklet with the selichot added. The great success induced him to become a peddler; his assortment, produced at his own expense, consisted of booklets, portraits of rabbis and other Hebrew printed matter. In 1837 he obtained the licence to open a bookshop. His editorial activity was interrupted by the revolutionary events of 1848 and the repressions which followed so that for four years he could not proceed with it. The fruits of his editorship were much valued and he is mentioned in a majority of older Jewish Encyclopedias ${ }^{3,4}$. For his work he was awarded the Great Golden Imperial Medal "Viribus Unitis" in $1855^{5}$. He bequeathed his enterprise ${ }^{6}$ to his wife and son Jacob W. Pascheles (2 January 1839, Prague 23 November 1897, Prague); the latter continued successfully the editorial work of his father. Jacob W. Pascheles was Wolfgang Pauli's grandfather, a respected member of the Jewish community of Prague (see the German inscription on his tombstone, Fig. 1).

The Prague Directory ${ }^{7}$ lists his establishment as a "bookshop, secondhand booksellers and publishers of Hebrew books" in Staroměstské náměstí (Old Town Square, Altstädter Ring) 11/608. This house still stands next to Kinsky palace where at that time the "Deutsches Staatsgymnasium PragAltstadt" was located. The living quarters of the Pascheles family were in the house no. 7/930 in the same square (see Fig. 2).

Wolf Pascheles, a son of Jacob W. and Helene née Utitz, was born on 11 September 1869 in Prague. In the school year 1879/1880, the boy started to attend the abovementioned "Gymnasium". His marks were very good, though he did not earn any honours ${ }^{8,9}$. Attending facultative classes as a 


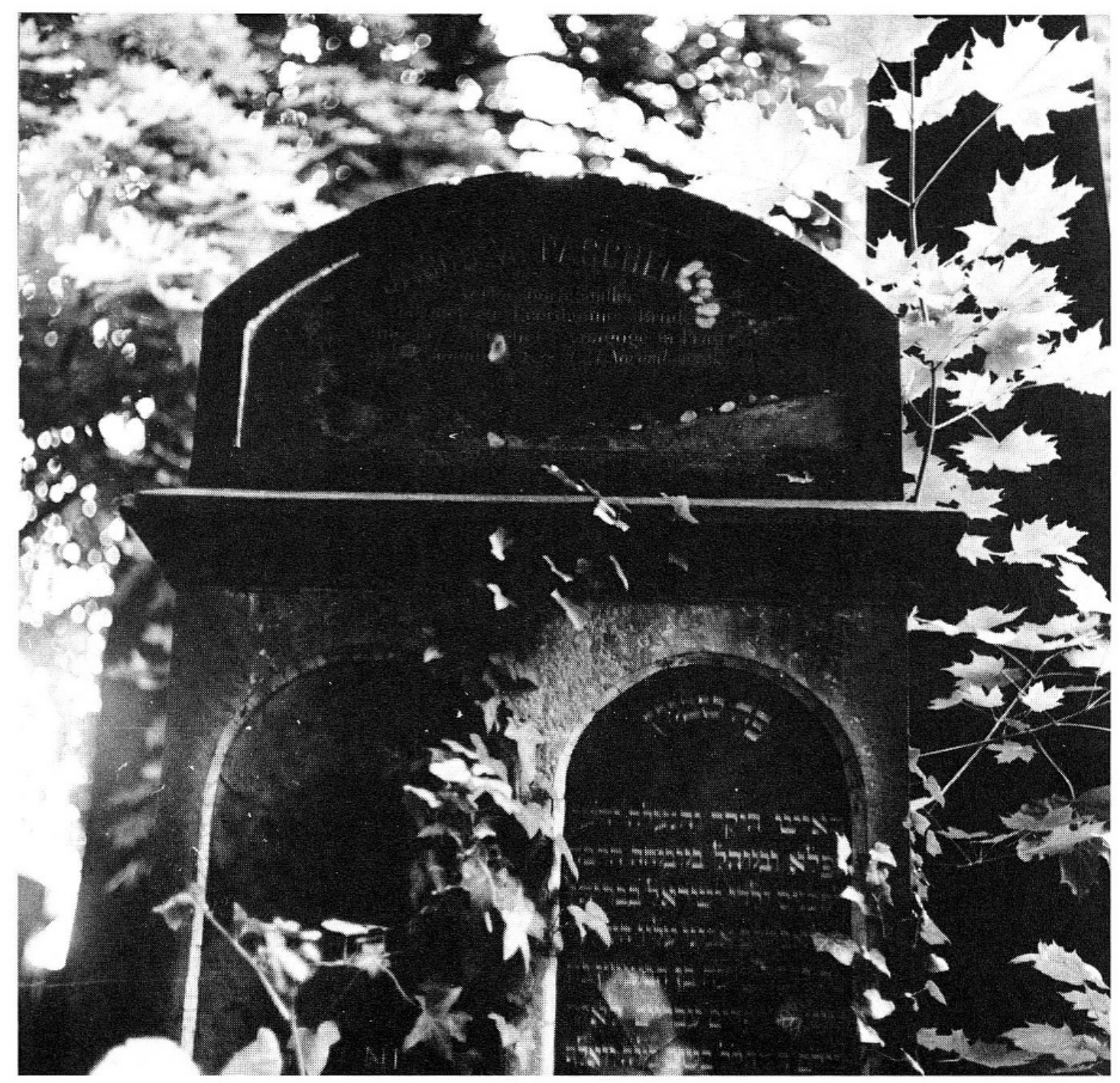

Fig. 1

junior, he had learned Czech, later on French and shorthand. He passed the final examination on 9 July 1887.

Of the atmosphere of the town and particularly the school, we have indirect but detailed accounts in the biographies of Franz Kafka ${ }^{10,11}$ who became a student at the same "Gymnasium" only six years after Wolf Pascheles finished it. Amongst the voices of the contemporaries, often youthfully critical, sounds Max Brod's: "At the Old-Town Gymnasium, there were only (underlined by M.B.) good students ...". The Pascheles and Kafka families were acquainted. For this statement speaks not only the fact that the Kafkas also lived in the Old Town Square in the years 1889-1896, 


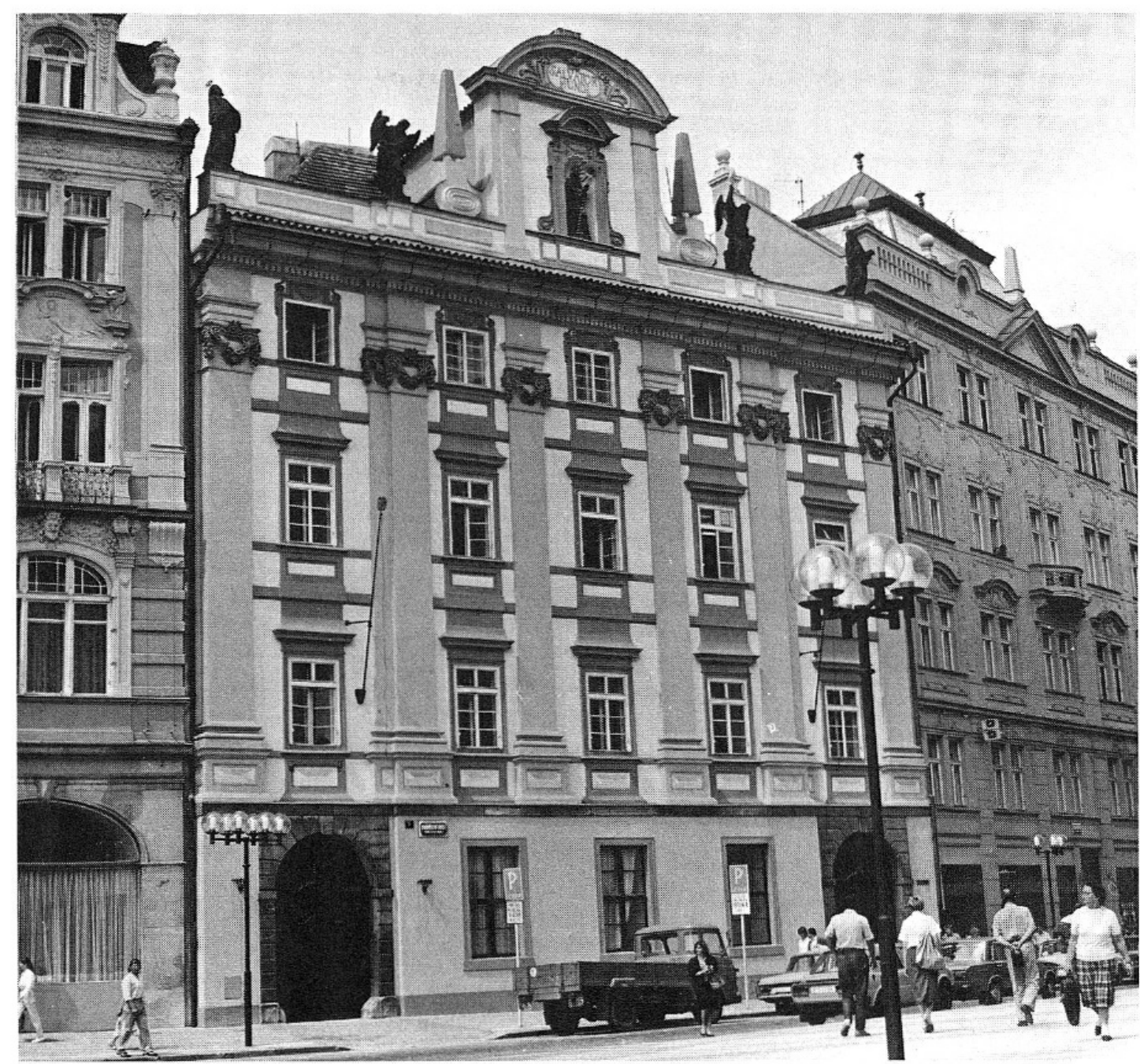

Fig. 2

and after 1896 in Celetná street no.3. Incidentally, at Celetná street no. 4 lived Samuel W. Pascheles, the younger brother of Jacob, who there also had a shop which he himself called "retail stationery, bookstore, works of art and music, sale of Hebrew books and ritualia"7. The same source lists the Pascheles brothers in the Register of Sworn Experts at the Imperial and Royal State Court (Landesgericht) in Prague as the only two experts in the matter of Hebrew books.

For a certain period of time, the Kafkas also belonged to the congregation of the "Zigeuner Synagoge" (Gipsy's Synagogue, called by the nickname of a certain Solomon Shalkid, the founder, 1613) where on 18 June 1896 Franz 
Kafka passed the "confirmation" (in the circles of Franz Kafka's parents this was the name used for bar mitzwah). But the elder (Vorsteher) of the congregation was ... Jacob W. Pascheles ${ }^{12}$.

In 1887, Wolf Pascheles matriculated at the Faculty of Medicine of the German Carl-Ferdinand University in Prague. He passed with honours all three examinations for the doctor's degree (I: 16 December 1890; II: 11 October 1892; III: 21 April 1893), and on 24 April 1893 he obtained the M. univ. Dr. degree ${ }^{13}$. My attempts to find out the exact time at which the young doctor moved to Vienna were unsuccessful. But shortly after the death of his father Jacob he applied for the permission to change his surname from Pascheles to Pauli, which was granted on 28 July $1898{ }^{14}$. Before that he had changed his faith to catholic. And the following year, on 2 May 1899, he married Bertha Camilla Schütz ${ }^{15}$.

\section{3 - Professor Mach and his family}

Ernst Mach (18 February 1838, Chrlice near Brno-19 September 1916, Vaterstetten near Munich) spent most of his active life in Prague: From 1867 to 1895 he was professor of experimental physics at the Carl-Ferdinand University. In 1867 he married Louise Marussig; his son Ludwig was born on 10 November 1868. In the years 1879-1883, Ludwig Mach attended the same "Gymnasium" as Wolf Pascheles did. The first three years, he belonged to the second of the two parallel classes; in "quarta", which in the school year $1882 / 83$ was not split, he is listed in the class catalogue as a son of "State Councillor and University Professor" 8,9. Then, however, the classmates Ludwig Mach and Wolf Pascheles had to part company: Wolf Pascheles remained at the "Gymnasium" whereas Ludwig Mach continued his classes as an external private. We have been able to identify him in preserved documents only as "octavane" and public student of "k.k. Staats-Obergymnasium" in Hostinné (Arnau) ${ }^{16}$ at the foothills of the Krkonoše (Riesengebirge). There he also passed his final examination in $1887^{17}$.

The young gentlemen forgathered again in Prague in 1887: Ludwig Mach matriculated at the Medical Faculty of the German Carl-Ferdinand University simultanously with Wolf Pascheles. It is interesting to note that, in the winter semester of $1887 / 88$, professor Mach, besides his famous regular 
course "Experimental Physics" and for the last time during his activity in Prague, also taught "Practicum of Physics for Medical Students". In subsequent years he gave courses on "Introduction to Independent Work in Physics", and still later on "Selected Chapters from the Theory of Heat" and on "Optical Exercises for Beginners"18. Whether classmates Wolf and Ludwig frequented "Practicum of Physics for Medical Students" cannot be proved since the detailed records and Student Catalogues of the Medical Faculty of the German Carl-Ferdinand University covering the years in question are lost; in the given context it seems nevertheless nearly certain. With a satisfactory degree of reliability this circumstance may therefore be considered as a starting point for the influence of professor Mach on the young student Wolf Pascheles.

The quite extraordinary pedagogical qualities of Professor Mach and his intensive intellectual influence, both direct and mediated, on students, colleagues, friends, the scientific community as well as the interested public, were stressed by many independent witnesses (see, e.g., ref. 19 and further works mentioned therein). I think it timely to mention the fact that at the end of the eighties and during the nineties, Professor Mach considered it a must to prepare a series of textbooks for various kinds of German secondary schools ${ }^{20}$ and found sufficient time for lectures open to the public. In 1891 he accepted ordinary membership in the "Society for the Advancement of German Science, Art and Literature in Bohemia" ${ }^{21}$, a fact which is not often mentioned in Czech papers on Ernst Mach.

Since I do not consider myself qualified for drawing up my own interpretation of the reasons leading to the move of professor Mach to Vienna and since I do not feel compelled to accept any one of the so-called readily occuring motives ${ }^{22}$, I shall finish this section by pointing to an interesting fact: Professor Mach and his family moved to Vienna in the same year that his son Ludwig was promoted to "M. univ. Dr." at the Medical Faculty of Carl-Ferdinand University on 5 July $1895^{23}$. Combining the facts presented here with the well-known atmosphere of "enlightened antisemitism" shrouding many German and Austrian universities at the time (a good description of the climate, as well as narratives on well-known individuals are presented in ref. 24), I suggest that the query mentioned in the introduction may be answered as follows: Godfathering of Wolfgang Pauli in 1900 should be considered as a progressive act and an authoritative support of the career of a young scientist and friend of his son by a man who actively fought for atheism, but who certainly was not at all narrow-minded. 


\section{4 - The surname and the house}

This part of the paper perhaps should not have been written. In comparison with the preceding sections, where facts are presented, here I wish to suggest a hypothesis on the motive that induced the young convertite Wolf Pascheles to select out of all possible surnames just this one: Pauli.

Ninety years ago, when legally selecting a new surname, irrespective of social standing, parentage or religion, preservation of initials was much more exigent than nowadays. Moreover, Jewish converts often strove to preserve not only the first letter of the old surname, but if possible a few more letters as well. The change Pascheles-Pauli well obeys this tendency but this tendency alone almost does not narrow the possible choices.

We may think of distinguished bearers of the surname Pauli known to Wolfgang Pascheles, or suppose such an example to exist among his contemporaries. Even in the Prague of those days there were many Paulis to select from: an opera singer, a heroine of dramatic theatre, an establishment of a nobleman (vine merchant) and others ${ }^{7}$. One may seek a connection with the best known convert: Saint Paul of the New Testament ... But we have one more motive which must have been known to Wolf Pascheles from his young days since it is connected with the history of the house of his parents in the Old Town Square. To doubt the knowledge of this motive in a family of well-educated editors seems impossible:

The house at Staroměstské náměstí no. $7 / 930$ is a former convent of Paulans (Minims of St. Francis of Paola, originally known as Hermits of St. Francis of Assisi). The convent (see Fig. 3) existed till the Josephine era when it was abolished, as it happened to many others. I do not think it necessary to call in an expert to determine the most probable spelling of the words: Paulan-Paulans-Paulanian, as they might have been used in a Germanspeaking Jewish family in Prague in the second half of the last century. It is perhaps sufficient to show forms appearing in the preserved bills to the convent made out (in German) by Prague artisans at the end of the 17th century ${ }^{25}$ : Paulaner, Pauliner, Paulliner, Paulanher.

Somewhere, perhaps, there is a testimony containing the reasons which Wolf Pascheles stated when asked for his new surname Pauli, or which he might have expressed afterwards. I think that such a testimony should not be searched for intentionally. One day to come, such a testimony may be discovered by chance and the finder, after pondering over the ethics of the case, may decide to publish it. But at present, I merely suggest a hypothesis 


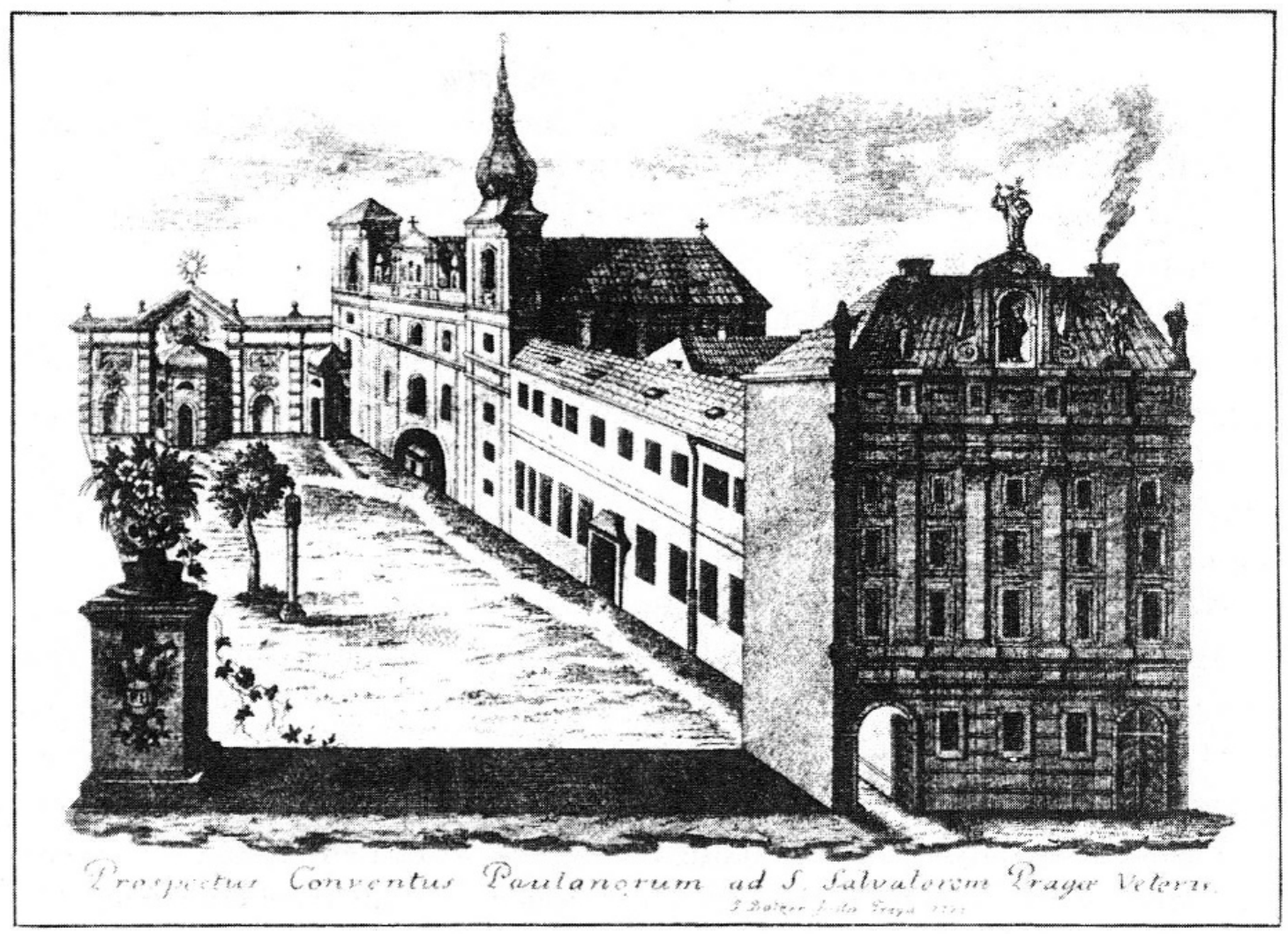

Fig. 3

on the motive of selecting the surname Pauli, based on Wolf Pascheles' feeling of congruence with the family, the paternal house built by ancient friars, and the town where he grew up ...

I confess that any of my future encounters with the person and work of the physicist Wolfgang Pauli, Nobel Laureate of 1945, will bring about a passing reminiscence of the old convent ad St. Salvatorem in the most distinguished square of Prague, my City.

Acknowledgments. Having searched in the Archives, I met with many kind and understanding persons. Especially, my cordial thanks are due to Dr. V. Hamáčková of the State Jewish Museum in Prague, to Dr. T. Jelínek of the Prague Town Archives, to Dr. M. Kunštát of the Archives of Charles University and to the director of the County Archives in Trutnov, Dr. V. Vaňková. Last but not least I wish to thank Prof.C.P. Enz, University of Geneva, for having directed me toward this research. 


\section{References}

1 Übersicht der akademischen Behörden, Professoren, Privatdocenten, Lehrer, Beamten etc. an der k.k. Universität zu Wien für das Studienjahr 1899/1900, S. 31:

"Wolfgang Pauli, M. univ. Dr., Privatdocent für interne Medicin; Mitgl. d. k.k. Gesellsch. d. Ärzte, d. physiolog. Club u. d. Gesellsch. f. Neurologie u. Psychiatrie; wohnhaft Wien 1., Gluckgasse 1."

2 "Unter meinen Büchern befindet sich ein etwas verstaubtes Etui, in diesem ist ein Silberbecher im Jugendstil und in diesem wiederum ist eine Karte ... Dieser Becher nun ist ein Taufbecher und auf der Karte steht in altmodisch verschnörkelten Buchstaben: 'Dr. E. Mach, Professor an der Universität Wien.' Es kam so, dass mein Vater sehr mit seiner Familie befreundet war, damals geistig ganz unter seinem Einfluss stand und er (Mach) sich freundlicherweise bereit erklärt hatte, die Rolle des Taufpaten bei mir zu übernehmen ..."

From: Charles P. Enz, "W. Pauli's Scientific Work" in "The Physicist's Conception of Nature", ed. Jagdish Mehra (Reidel, Dordrecht, 1973), note 2, p. 792. See also C. P. Enz, "Wolfgang Pauli, Physiker und Denker des 20. Jahrhunderts" in "Wolfgang Pauli, Das Gewissen der Physik", ed C. P. Enz und K. von Meyenn(Vieweg, Braunschweig, 1988), S. 4.

3 "Jewish Encyclopedia" (Funk and Vagnalls and Co, New York-London, 1905), vol. IX, p. 546.

4. "Jüdisches Lexikon" (Jüdischer Verlag, Berlin, 1928), Band IV/1; see also S. Wininger, "Grosse Jüdische National-Biographie" ("Orient" und "ARTA", Czernowitz, 19251936) Band IV, S. 610.

5 "Allgemeine Zeitung des Judenthums" (Leipzig) 19, No. 8 (19. Februar 1855), S. 95.

6 Ibid. 22, No.2 (4. Januar 1858), S. 22.

7 Adressár král. hlavn. města Prahy a sousedních obcí ..., Obec král. hl. města Prahy, redakcí Václava Lešera v Praze 1896. (Prague Directory; in Czech).

8 Archiv hl. města Prahy (Prague Town Archives; abbreviated as AMP) Klassenkataloge Deutsches Staatsgymnasium Prag-Altstadt: I. B Classe 1879/80; III. A Classe 1881/82; III. B Classe 1881/82; IV. Classe 1882/83; V. Classe 1883/84 (no reg. nos.).

9 AMP: Zehnter ... Fünfzehnter Jahresbericht über das Deutsche Staatsgymnasium in Prag-Altstadt für das Schuljahr 1881/82 ... 1886/87.

10 Klaus Wagenbach, "Franz Kafka" (Rowohlt Taschenbuch, Reinbek bei Hamburg, 1964).

11 Max Brod, "Über Franz Kafka" (Fischer Taschenbuch, Frankfurt a. M., 1974).

12 "Jacob W. Pascheles Verlagsbuchhändler, Vorsteher der isr. Beerdigungs-Bruderschaft und der Zigeuner-Synagoge in Prag, geb. 2. Januar 1839, gest. 23. November 1897." (Cf. Fig.1; grave no. 6-11-1, Jewish cemetery, Prague 3, Nad vodovodem 1.)

13 Archiv Karlovy university (Arehives of Charles University; abbreviated as AUK NU), H. Rig. Prot., med. Fakultät, 1885-1911, no pagination; also AUK NU, Doktoren Matrik, Band 2, I 1892-1904, S.13.

14 "Der Bräutigam hat lt. Erlass der K.K. Österreichischen Statthalterei vom 28.7.1898 Zl. 59092 die Bewilligung zur Änderung seines Familiennamens Pascheles in Pauli erhalten."

From: Traubuch, Pfarre Währing, Wien 18., Maynollogasse 3. 
15 Traubuch, Pfarre Währing.

16 OA Trutnov (County Archives in Trutnov), Fund RG Hostinné, book no. 107: Hauptprotokoll der Maturitäts-Prüfung im Schuljahr 1886/87, S.11.

17 OA Trutnov, Fund RG Hostinné, book no. 6: Sechster Jahresbericht über das k.k. StaatsObergymnasium in Arnau, veröffentlicht am Ende des Schuljahres 1886/87, S.61.

18 Ordnung der Vorlesungen an der k.k. deutschen Carl-Ferdinands-Universität zu Prag im Wintersemester 1887/88 ... Sommersemester 1895.

19 Ivo Tretera, "Casus Štěpán Doubrava. Unbekannte Briefe von Ernst Mach an August Seydler aus dem Jahre 1882", Acta Universitatis Carolinae - HUCP 25, 59-94 (1985).

20 Joachim Thiele, "Ernst Mach - Biographie", Centaurus 8, 189-237 (1963).

21 Personalstand der k.k. deutschen Universität zu Prag 1882/83 ... 1894/95.

22 Otto Blüh, "Ernst Mach-His Life as a Teacher and Thinker", in "Ernst Mach-Physicist and Philosopher", ed. Robert S. Cohen and Raymond J. Seeger (Reidel, Dordrecht, 1970), 1-22; and further works mentioned therein.

23 AUK NU, Doktoren Matrik, Band 2/I: 1892-1904, S.94.

24 D. Nachmansohn, "German-Jewish Pioneers in Science 1900-1933" (Springer, New York, 1979).

25 Vilém Pohl, "Quelques documents relatifs à l'ancien couvent de l'Ordre de St-François de Paule à Staroměstské náměstí“, Památky archeologické (Monuments Archéologiques, Revue pour l'archéologie préhistorique et pour l'histoire des beaux-arts en Tchéco-Slovaquie; articles in Czech, French summaries) 35, 632-640 (1926, 1927).

\section{Figure Captions}

Fig. 1: The tombstone of Wolfgang Pauli's grandfather in the Jewish cemetery, Prague 3. German inscription: "Jacob Pascheles / Verlagsbuchhändler/ Vorsteher der isr. BeerdigungsBruderschaft / und der Zigeuner-Synagoge in Prag / geb. 2. Januar 1839 gest. 23. November 1897." (Photo by F. S.)

Fig. 2: House no. 7/930 at the Old Town Square, Prague, present state (Photo by F. S.).

Fig. 3: J. Balzer's prospectus (1771) of the Paulans' convent in the Old Town Square in Prague. In order to show the whole complex, houses then forming, together with the southern front of the convent, the northern side of the square, are omitted.

\section{Résumé}

\section{Ernst Mach et les ancêtres de Wolfgang Pauli à Prague}

Le physicien suisse Wolfgang Pauli (1900-1958) est issu d'une famille de notables juifs, éditeurs et libraires à Prague. Cet essai présente des données biographiques concernant la vie à Prague de son père, son grand-père et son arrière-grand-père. Les origines de l'amitié entre le père de Wolfgang Pauli et la famille d'Ernst Mach, alors professeur à l'Université de Prague, sont mises en évidence et une hypothèse est formulée à propos des motifs qui ont amené Wolf Pascheles, le père de Wolfgang Pauli, à choisir précisément «Pauli» comme nouveau nom de famille. 


\section{Zusammenfassung}

\section{Ernst Mach und die Vorfahren Wolfgang Paulis in Prag}

Der Schweizer Physiker Wolfgang Pauli (1900-1958) stammt aus einer angesehenen jüdischen Familie von Verlegern und Buchhändlern in Prag. Dieser Aufsatz vermittelt biographische Daten und Prager Schicksale seines Vaters, Grossvaters und Urgrossvaters. Die Wurzeln der Freundschaft zwischen Wolfgang Paulis Vater und der Familie von Ernst Mach, der damals Professor an der Universität Prag war, werden aufgezeigt, und es wird eine Hypothese vorgeschlagen betreffend die Motive, die Wolf Pascheles, den Vater Wolfgang Paulis, veranlaßten, als neuen Familiennamen gerade «Pauli» zu wählen.

František Smutný, Ph.D.

Institute of Physics

Czechoslovak Academy of Sciences

Prague, ČSSR

Correspondence may be addressed to:

Professeur Charles P. Enz, Ph.D.

Département de physique théorique

Université de Genève

24, quai Ernest-Ansermet

CH-1211 Genève 4 